\title{
Synthesis and Characterization of Copper Impregnated Mesoporous Carbon as Heterogeneous Catalyst for Phenylacetylene Carboxylation with Carbon Dioxide
}

\author{
Putri Nurul Amalia, Iman Abdullah*, Dyah Utami Cahyaning Rahayu, and Yuni Krisyuningsih \\ Krisnandi
}

Department of Chemistry, Faculty of Mathematics and Natural Sciences, Universitas Indonesia, Depok 1642, Indonesia

\author{
* Corresponding author: \\ email: iman.abdullah@sci.ui.ac.id
}

Received: December 21, 2019

Accepted: July 20, 2020

DOI: $10.22146 /$ ijc. 52778

\begin{abstract}
Carbon dioxide $\left(\mathrm{CO}_{2}\right)$ is a compound that can potentially be used as a carbon source in the synthesis of fine chemicals. However, the utilization of $\mathrm{CO}_{2}$ is still constrained due to its inert and stable nature. Therefore, the presence of a catalyst is needed in $\mathrm{CO}_{2}$ conversion. This study aims to synthesize copper impregnated mesoporous carbon $(\mathrm{Cu} / \mathrm{MC})$ as a catalyst for phenylacetylene carboxylation reaction with $\mathrm{CO}_{2}$ to produce phenylpropiolic acid. The synthesis of mesoporous carbon was performed via the soft template method. The as-synthesized Cu/MC material was characterized by FTIR, $S A A, X R D$, and SEM-EDX. BET surface area analysis of mesoporous carbon showed that the material has a high surface area of $405.8 \mathrm{~m}^{2} / \mathrm{g}$ with an average pore diameter of $7.2 \mathrm{~nm}$. XRD pattern of $\mathrm{Cu} / \mathrm{MC}$ indicates that $\mathrm{Cu}$ has been successfully impregnated in the form of $\mathrm{Cu}(0)$ and $\mathrm{Cu}(\mathrm{I})$. Phenylacetylene carboxylation reaction with $\mathrm{CO}_{2}$ was carried out by varying reaction temperatures $\left(25,50\right.$, and $\left.75{ }^{\circ} \mathrm{C}\right)$, amount of catalyst $(28.6,57.2$, and $85.8 \mathrm{mg}$ ), type of base $\left(\mathrm{Cs}_{2} \mathrm{CO}_{3}, \mathrm{~K}_{2} \mathrm{CO}_{3}\right.$, and $\left.\mathrm{Na}_{2} \mathrm{CO}_{3}\right)$, and variation of support. The reaction mixtures were analyzed by HPLC and showed that the highest phenylacetylene conversion of $41 \%$ was obtained for the reaction at $75{ }^{\circ} \mathrm{C}$ using $\mathrm{Cs}_{2} \mathrm{CO}_{3}$ as a base.
\end{abstract}

Keywords: carbon dioxide; mesoporous carbon; copper; catalyst; phenylacetylene; carboxylation reaction

\section{- INTRODUCTION}

Carbon dioxide $\left(\mathrm{CO}_{2}\right)$ is a compound that can potentially be used as a carbon source and an attractive $\mathrm{C} 1$ building block in organic synthesis due to its intriguing features, such as being non-toxic, renewable, inexpensive, and readily available [1]. But in reality, utilization and large-scale $\mathrm{CO}_{2}$ conversion are still limited due to thermodynamic stability and inert nature, making $\mathrm{CO}_{2}$ difficult to react with other compounds. Thus, a lowvalence metal is needed as a catalyst to activate $\mathrm{CO}_{2}[2]$.

Various types of transition metals have been extensively studied in their capacity as catalysts for $\mathrm{CO}_{2}$ utilization in fine chemical synthesis. Nickel is one of the most studied in the carboxylation reaction using $\mathrm{CO}_{2}$ as a carbon source. Various types of substrates have been investigated in carboxylation reactions using nickel catalysts such as alkynes [3], ynamides [4-5], alkenes [6], and alkyl halides [7], and the results show that the nickel works well in catalyzing the reaction. However, the instability of $\mathrm{Ni}(0)$ becomes an obstacle in the use of $\mathrm{Ni}$ as a catalyst. In nickel as a catalyst, reducing agents such as reactive metals or pyrogenic organozinc are often added in large quantities to keep the $\mathrm{Ni}(0)$ species in existence during the reaction [3-4,6]. Other transition metals from noble metals such as $\mathrm{Au}, \mathrm{Pt}, \mathrm{Ag}$, and $\mathrm{Pd}$ are also known to have good activity as catalysts in carboxylation reactions [8-11]. However, the use of these metals in industrial-scale applications is constrained by high production costs. Another transition metal that is quite promising as a carboxylation reaction catalyst is copper. It is known that catalysts containing $\mathrm{Cu}$ or $\mathrm{Ag}$ are suitable for activating the $\mathrm{C}-\mathrm{C}$ triple bond generally for carboxylation with $\mathrm{CO}_{2}$, and $\mathrm{Cu}$ is also the only element that can make $\mathrm{C}-\mathrm{C}$ bonds directly from $\mathrm{CO}_{2} \mathrm{RR}$ with good selectivity [2,12-15]. In this context, the direct 
carboxylation of terminal alkynes with $\mathrm{CO}_{2}$ is the simplest and most straightforward way to access alkynyl carboxylic acids [1]. Recently, Wang et al. [16] reported that $\mathrm{CuCl}$ is an efficient catalyst for carboxylation of terminal alkynes in the presence of quaternary ammonium salts as a $\mathrm{CO}_{2}$ activator. The reaction proceeded well under ligand-free conditions to give high to excellent yields of various propionic acids. However, the catalytic system is still homogeneous, which is relatively less preferred for industrial applications than the heterogeneous one.

Meanwhile, in terms of catalyst support, mesoporous carbon is a material known to have several advantages, such as a large pore diameter $(2-50 \mathrm{~nm})$, regularly arranged pores, and high thermal stability [1718]. These advantages make mesoporous carbon good catalyst support. It can assist the loading process of active catalyst species, facilitate good reactant transport, and expand the temperature range in reaction applications. It is known that mesoporous carbon can be impregnated well with various types of metals for multiple applications such as Ag [19-20], Pd [20], Ni [21-22], Co [23], Ru [24], and $\mathrm{Cu}$ [25]. In addition, mesoporous carbon is also a potential material to be used as a $\mathrm{CO}_{2}$ adsorbent [26-27]. Based on previous studies, it can be seen that mesoporous carbon is good solid catalyst support as well as a potential $\mathrm{CO}_{2}$ adsorbent. Thus, the present work was aimed to synthesize $\mathrm{Cu}$ impregnated on mesoporous carbon prepared by the soft-template method. Structural changes that occur in mesoporous carbon after the impregnation process was studied through several characterizations such as SEM-EDX, XRD, and SAA and are compared with the phenomenon that occurs in activated carbon as a comparison. Furthermore, we also tested the catalytic activity of the impregnated $\mathrm{Cu}$ on mesoporous carbon $(\mathrm{Cu} / \mathrm{MC})$ in the carboxylation of phenylacetylene with $\mathrm{CO}_{2}$ to produce carboxylic acid under mild conditions.

\section{- EXPERIMENTAL SECTION}

\section{Materials}

Pluronic F-127, phloroglucinol (>99.0\%), $\mathrm{HCl}(37 \%)$, formaldehyde (37\%), $\mathrm{Cu}\left(\mathrm{NO}_{3}\right)_{2} \cdot 3 \mathrm{H}_{2} \mathrm{O}$, phenylacetylene (98\%), DMF (99.8\%), $\mathrm{Cs}_{2} \mathrm{CO}_{3}, \mathrm{~K}_{2} \mathrm{CO}_{3}$, and $\mathrm{Na}_{2} \mathrm{CO}_{3}$ were obtained from Sigma Aldrich, while ethanol, methanol, and acetic acid were from Merck. All materials were used directly without any further purification. All ultra-high purity gases $\left(\mathrm{CO}_{2}, \mathrm{H}_{2}\right.$, and $\left.\mathrm{N}_{2}\right)$ were purchased from $\mathrm{CV}$ Retno Gas, Jakarta.

\section{Procedure}

\section{Preparation of mesoporous carbon (MC)}

The synthesis of mesoporous carbon as catalyst support was done through the soft-template method using Pluronic F-127 as a pore-forming, formaldehyde and phloroglucinol as carbon sources, and $\mathrm{HCl}$ as an acid catalyst [28]. Approximately $1.25 \mathrm{~g}$ of phloroglucinol and $1.25 \mathrm{~g}$ of Pluronic F127 were dissolved in a mixture of ethanol: water (10:9 wt.\%). Then, $0.08 \mathrm{~mL}$ of $37 \% \mathrm{HCl}$ was added, and the mixture was stirred for $30 \mathrm{~min}$, followed by adding $1.25 \mathrm{~mL}$ of $37 \%$ formaldehyde still under stirring. After $30 \mathrm{~min}$, the solution's color became cloudy, and after $1-2 \mathrm{~h}$, the mixture was separated into two phases. The lower phase was taken and stirred for $12 \mathrm{~h}$ to form a monolith, which then was heated at $100^{\circ} \mathrm{C}$ for $24 \mathrm{~h}$. Furthermore, the material was carbonized in tubular furnaces under $\mathrm{N}_{2}$ gas flow with heating profile as follow: from 100 to $400^{\circ} \mathrm{C}$ with a flow rate of $1{ }^{\circ} \mathrm{C} / \mathrm{min}$; from 400 to $850{ }^{\circ} \mathrm{C}$ with a flow rate of $5{ }^{\circ} \mathrm{C} / \mathrm{min}$; and finally with a temperature of $850^{\circ} \mathrm{C}$ for $2 \mathrm{~h}$.

\section{Preparation of Cu/MC catalysts}

The as-synthesized mesoporous carbon was then impregnated with copper metal $(\mathrm{Cu} / \mathrm{MC})$ according to a previously reported method [13]. The procedure was carried out by dissolving $0.592 \mathrm{~g}$ of $\mathrm{Cu}\left(\mathrm{NO}_{3}\right)_{2} \cdot 3 \mathrm{H}_{2} \mathrm{O}$ in $24.5 \mathrm{~mL}$ of water, and then $1.4 \mathrm{~g}$ of mesoporous carbon was added to the solution. The mixture was stirred for $1 \mathrm{~h}$ while heated at $80^{\circ} \mathrm{C}$. The mixture was further dried in an oven at $110^{\circ} \mathrm{C}$ for $24 \mathrm{~h}$, followed by reduction with $\mathrm{H}_{2}$ gas with a flow rate of $15-20 \mathrm{~mL} / \mathrm{min}$ at $300{ }^{\circ} \mathrm{C}$ for $3 \mathrm{~h}$ in a tubular furnace. In addition to mesoporous carbon as catalyst support, commercial activated carbon (AC) was also tested as a comparison. Prior to use, the activated carbon was modified using $\mathrm{HNO}_{3}$ acid according to the previously reported method [29]. The impregnation of $\mathrm{Cu}$ on $\mathrm{AC}$ was conducted using the same method as that of $\mathrm{Cu} / \mathrm{MC}$. The prepared catalysts $(\mathrm{Cu} / \mathrm{MC}$ and $\mathrm{Cu} / \mathrm{AC})$, as well as the supports (MC and 
AC), were characterized using X-ray diffraction (XRD PANalytical X'Pert PRO, K- $\alpha$ Cu of $1.54 \AA$ ), SEM-EDX (JEOL JED-2300 Analysis Station), and SAA (Quantachrome Quadrasorb-Evo Surface Area and Pore Size Analyzer). The average crystallite size of $\mathrm{Cu}$ on $\mathrm{Cu} / \mathrm{MC}$ was calculated using the Scherer equation as follows,

$\mathrm{D}=\frac{0.9 \lambda}{\beta \cos \theta}$

where $D$ is the average crystallite size $(\mathrm{nm}), \lambda$ is the wavelength of the $\mathrm{X}$-rays $(0.154 \mathrm{~nm}), \beta$ is the broadening of the diffraction peak measured at full-width halfmaximum in rad.

\section{Application of $\mathrm{Cu} / \mathrm{MC}$ as catalyst for carboxylation} reaction with $\mathbf{C O}_{2}$. Into a $30 \mathrm{~mL}$ batch reactor, phenylacetylene $(98.8 \mu \mathrm{L} ; 0.9 \mathrm{mmol}), \mathrm{Cu} / \mathrm{MC}(28.6 \mathrm{mg}$; $0.045 \mathrm{mmol}$ ), $\mathrm{Cs}_{2} \mathrm{CO}_{3}(58.6 \mathrm{mg} ; 1.8 \mathrm{mmol})$ and $\mathrm{DMF}$ $(9 \mathrm{~mL})$ were added. Then a $\mathrm{CO}_{2}$ gas balloon was attached to the reactor. Prior to the attachment of the $\mathrm{CO}_{2}$ balloon, $\mathrm{CO}_{2}$ gas was flowed into the reactor to remove the air in the reactor. The mixture was then stirred for $4 \mathrm{~h}$ under $\mathrm{CO}_{2}$ pressure of $1 \mathrm{~atm}$. The carboxylation reactions were conducted by varying the reaction temperature $(25,50$, $75^{\circ} \mathrm{C}$ ), the amount of catalyst (28.6; 57.2; and $85.8 \mathrm{mg}$ ), the type of base $\left(\mathrm{Cs}_{2} \mathrm{CO}_{3}, \mathrm{Na}_{2} \mathrm{CO}_{3}\right.$, and $\left.\mathrm{K}_{2} \mathrm{CO}_{3}\right)$, and the type of support (mesoporous carbon and activated carbon). The reaction mixtures were then acidified with $\mathrm{HCl}$ and analyzed using HPLC (Shimadzu Prominence 10) with the following measurement conditions: methanol and $1 \%$ acetic acid as solvent (volume ratio of 55:45, respectively), column C18 Diamonsil, the flow rate of $1.5 \mathrm{~mL} / \mathrm{min}$, and detected with UV-Vis detector at a wavelength of $254 \mathrm{~nm}$. Prior to HPLC analysis of reaction mixture, some phenylacetylene, phenylpropionic acid, and cinnamic acid standard solutions have been injected into the HPLC column to provide a calibration curve for determination of phenylacetylene conversion and the yield of the product. The carboxylation products were also characterized using FTIR (Shimadzu IR Prestige 21) to obtain functional group information of the samples.

\section{Study of phenylacetylene adsorption on Cu/MC}

The adsorption isotherm model was determined by conducting adsorption of phenylacetylene at various concentrations on $\mathrm{Cu} / \mathrm{MC}$. The phenylacetylene concentrations used were $500,750,1500$, and $2000 \mathrm{ppm}$ in DMF solvent. A total of $50 \mathrm{mg}$ of $\mathrm{Cu} / \mathrm{MC}$ catalyst was added to each $5 \mathrm{~mL}$ of phenylacetylene solution, and the mixture was stirred for $4 \mathrm{~h}$. The mixture was filtered, and the filtrate was analyzed by HPLC. The obtained data were then fitted to Langmuir, Freundlich, and Temkin isotherm adsorption model to find the most appropriate model for adsorption of phenylacetylene on $\mathrm{Cu} / \mathrm{MC}$. The isotherm equations are described as follows:

Langmuir $\mathrm{q}_{\mathrm{e}}=\frac{\mathrm{q}_{\max } \mathrm{K}_{\mathrm{L}} \mathrm{C}_{\mathrm{e}}}{1+\mathrm{K}_{\mathrm{L}} \mathrm{C}_{\mathrm{e}}}$ or $\frac{1}{\mathrm{q}_{\mathrm{e}}}=\frac{1}{\mathrm{q}_{\max } \mathrm{K}_{\mathrm{L}} \mathrm{C}_{\mathrm{e}}}+\frac{1}{\mathrm{q}_{\max }}$

Freunlich $\mathrm{qe}=\mathrm{K}_{\mathrm{F}} \mathrm{C}_{\mathrm{e}}^{1 / \mathrm{n}}$ or $\log \mathrm{q}_{\mathrm{e}}=\log \mathrm{K}_{\mathrm{F}}+\frac{1}{\mathrm{n}} \log \mathrm{C}_{\mathrm{e}}$

Temkin $\mathrm{q}_{\mathrm{e}}=\frac{\mathrm{RT}}{\mathrm{b}_{\mathrm{T}}} \ln \left(\mathrm{K}_{\mathrm{T}} \mathrm{C}_{\mathrm{e}}\right)$ or $\mathrm{q}_{\mathrm{e}}=\ln \mathrm{K}_{\mathrm{T}}+\frac{\mathrm{RT}}{\mathrm{b}_{\mathrm{T}}} \ln \mathrm{C}_{\mathrm{e}}$

where $C_{e}(m g / L)$ is the equilibrium concentration of phenylacetylene in DMF solvent, $\mathrm{q}_{\mathrm{e}}$ is the amount (mg) of phenylacetylene adsorbed per gram $\mathrm{Cu} / \mathrm{MC}, \mathrm{q}_{\max }$ ( $\mathrm{mg} / \mathrm{g}$ ) is the maximum adsorption capacity, $\mathrm{K}_{\mathrm{L}}, \mathrm{K}_{\mathrm{F}}$, and $1 / n, K_{T}$ and $b_{T}$ are the constant values related to each isotherm models.

\section{- RESULTS AND DISCUSSION}

\section{Characterization of Cu/MC Catalyst}

The $\mathrm{Cu} / \mathrm{MC}$ catalyst was characterized using SEMEDX, XRD, and SAA. Scanning Electron Microscopy (SEM) analysis was used to determine the morphology of the as-synthesized mesoporous carbon. Fig. 1(a) shows that the morphology of mesoporous carbon is quite smooth, and there are uniform pores on the surface. Meanwhile, Fig. 1(b) shows the impregnated $\mathrm{Cu}$ attached to the surface of mesoporous carbon. The figure also shows a change in the morphology of mesoporous carbon after the impregnation process, which indicates the partial closure of the MC pores by copper. Fig. 1(c) shows the impregnated $\mathrm{Cu}$ on activated carbon. The morphology of $\mathrm{Cu} / \mathrm{AC}$ is rougher than that of $\mathrm{Cu} / \mathrm{MC}$. Based on the characterization with Energy Dispersed X-Ray (EDX) spectroscopy, it is known that MC has a composition of $94.87 \%$ carbon and $5.13 \%$ oxygen, while $\mathrm{Cu} / \mathrm{MC}$ consists of $58.97 \%$ carbon, $4.84 \%$ oxygen, and $36.19 \%$ copper by mass (Fig. 2). The low 

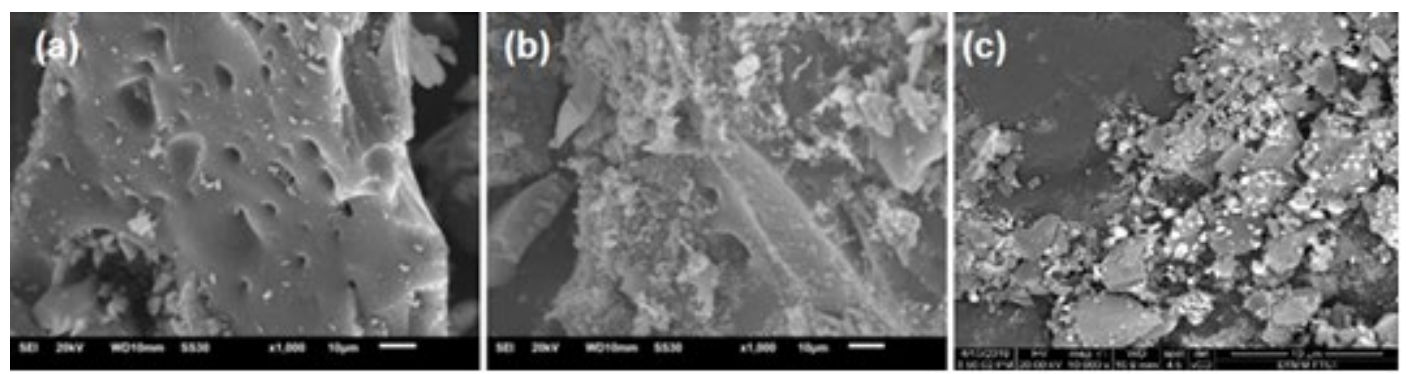

Fig 1. SEM micrograph of (a) MC, (b) $\mathrm{Cu} / \mathrm{MC}$ in $\times 1000$ magnification, and (c) $\mathrm{Cu} / \mathrm{AC}$ in $\times 5000$ magnification
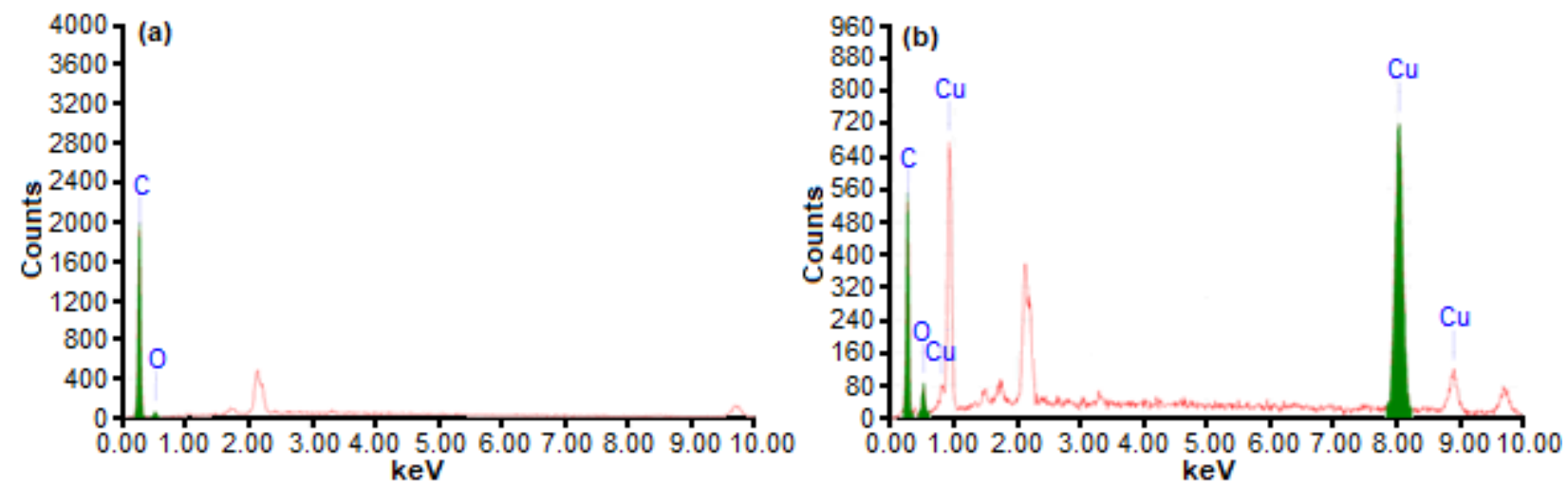

Fig 2. EDX spectrum of (a) $\mathrm{MC}$ and (b) $\mathrm{Cu} / \mathrm{MC}$

oxygen content of $\mathrm{Cu} / \mathrm{MC}$ indicates that copper has been successfully deposited on mesoporous carbon as $\mathrm{Cu}(0)$ metal as the dominant species.

The XRD patterns of the $\mathrm{Cu} / \mathrm{MC}$ sample in Fig. 3 exhibit characteristic diffractogram peaks of the metallic phase of $\mathrm{Cu}(0)$, which corresponds to $2 \theta$ values of $43.47^{\circ}$, $50.63^{\circ}$, and $74.19^{\circ}$ and of $\mathrm{Cu}(\mathrm{I})$, which corresponds to $2 \theta$ value of $36.62^{\circ}[13,25,29-30]$. This result indicates that two $\mathrm{Cu}$ species existed in $\mathrm{Cu} / \mathrm{MC}$ due to the reduction of copper(II) salt with hydrogen gas during calcination. The result is similar to that observed by Bondarenko et al. [13] for copper nanoparticles supported on $\mathrm{Al}_{2} \mathrm{O}_{3}$ prepared through the reduction of copper salt with hydrogen gas. Meanwhile, peaks of the mesoporous carbon support show $2 \theta$ values of $24.56^{\circ}$ and $43.94^{\circ}$, which is typical for carbon-based material according to JCPDS File Index No. 75-1621. Calculation using the Scherer equation from the diffraction peak at $43.47^{\circ}$ gives an average crystallite size of copper on $\mathrm{Cu} / \mathrm{MC}$ of $36.54 \mathrm{~nm}$.

Characterization using Surface Area Analyzer (SAA) was conducted to determine the surface character of mesoporous carbon, such as surface area, pore distribution, and pore diameter. In determining the surface

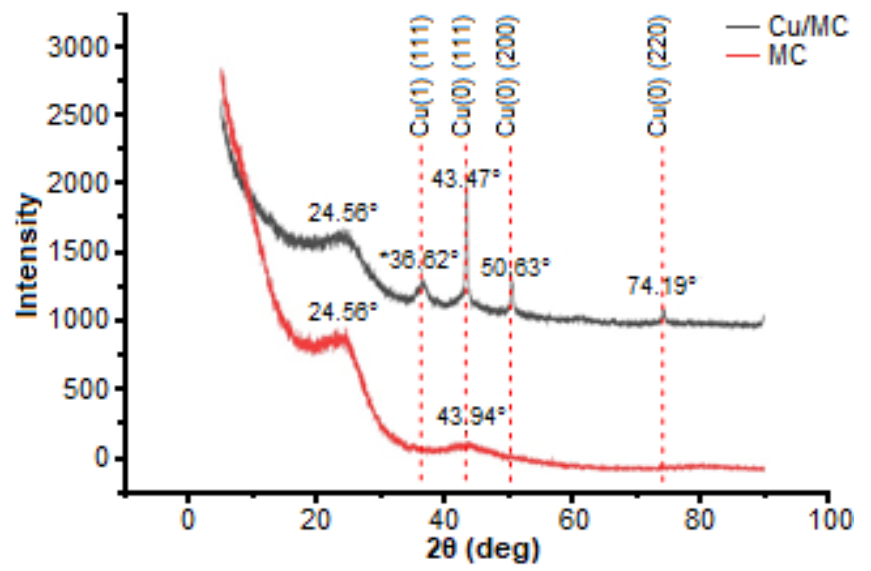

Fig 3. XRD patterns of mesoporous carbon (MC) and $\mathrm{Cu} / \mathrm{MC}$

area of a porous material, the method used is the Brunauer-Emmett-Teller (BET) method. The principle of measuring surface area with the BET method is based on the adsorption and desorption of $\mathrm{N}_{2}$ gas. Fig. 4(a) and (b) show that the synthesized mesoporous carbon and impregnated $\mathrm{Cu}$ on mesoporous carbon has an IV type of adsorption isotherm curve, where there is a hysteresis loop, which indicates that the pore is meso size [31]. Fig. $4(c)$ and (d) show the type of isotherm adsorption of AC 

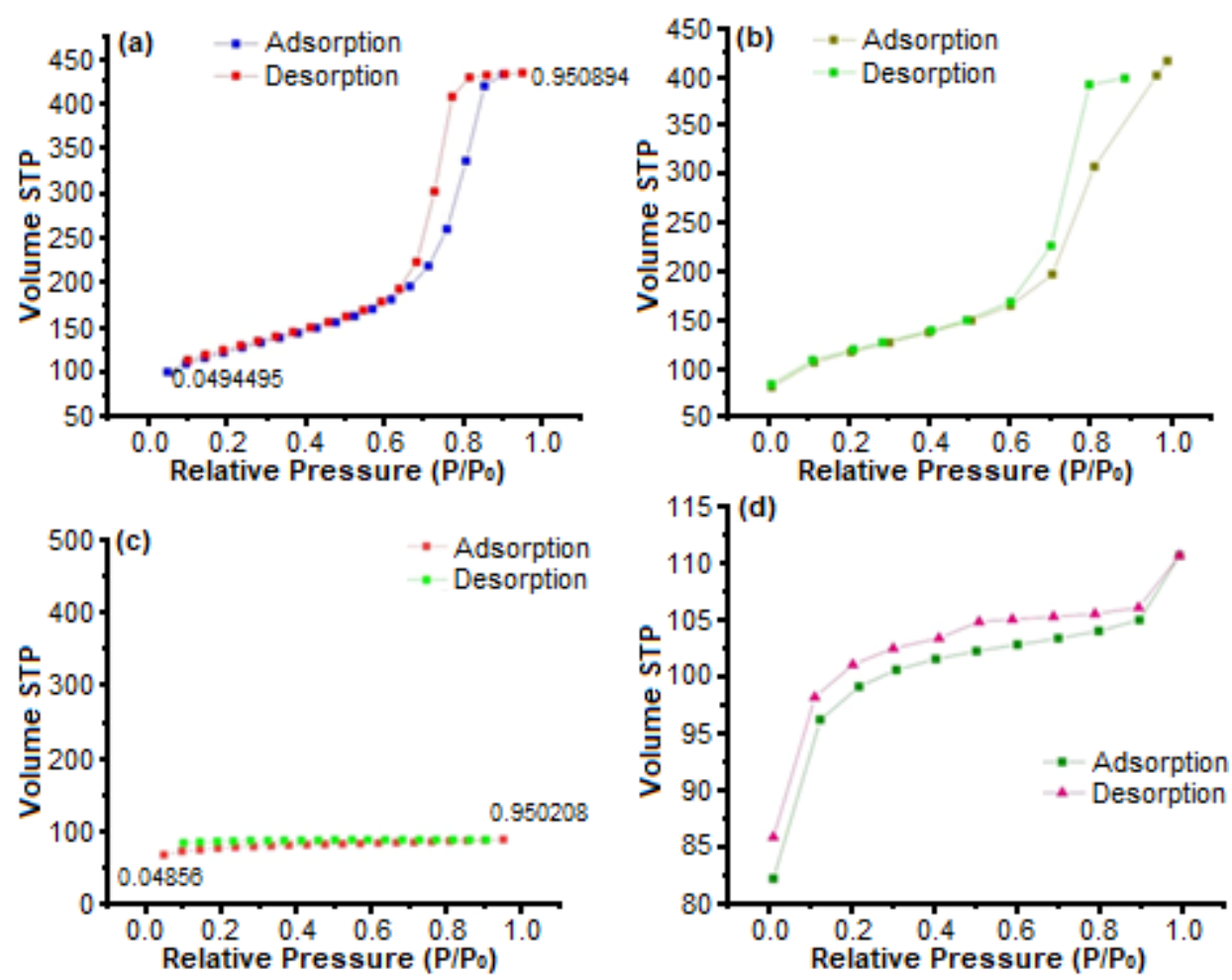

Fig 4. $\mathrm{N}_{2}$ adsorption/desorption of (a) $\mathrm{MC}$, (b) $\mathrm{Cu} / \mathrm{MC}$, (c) $\mathrm{AC}$, and (d) $\mathrm{Cu} / \mathrm{AC}$

and $\mathrm{Cu} / \mathrm{AC}$ satisfies the type I isotherm, which indicated the porosity is micro. Based on the BET calculation, it is found that the surface area of the synthesized mesoporous carbon is $405.78 \mathrm{~m}^{2} / \mathrm{g}$, which is almost double than that of activated carbon $\left(242.77 \mathrm{~m}^{2} / \mathrm{g}\right)$. The impregnation of copper on MC slightly lowered the surface area, mesopore volume, and the average of pore diameter. This result indicates that the copper species is possibly impregnated not only on the surface of MC but also inside its mesopore structure. Thus, the pore size distribution shifts slightly to a narrower size range (Fig. 5(a)). The contrary phenomenon is observed on $\mathrm{Cu} / \mathrm{AC}$. Copper impregnation increased the surface area from 242.77 to $307.06 \mathrm{~m}^{2} / \mathrm{g}$, which indicates that the presence of copper contributes to the rough surface of the material as shown by the SEM image, thus increasing its surface area. However, there were no significant changes in the pore size distribution, as shown in Fig. 5(b). This supports the previous explanation that copper is impregnated on the activated carbon's outer surface, and the micropore character remains unchanged. The complete data of the textural properties of $\mathrm{MC}, \mathrm{Cu} / \mathrm{MC}, \mathrm{AC}$, and $\mathrm{Cu} / \mathrm{AC}$ obtained from SAA are summarized in Table 1.
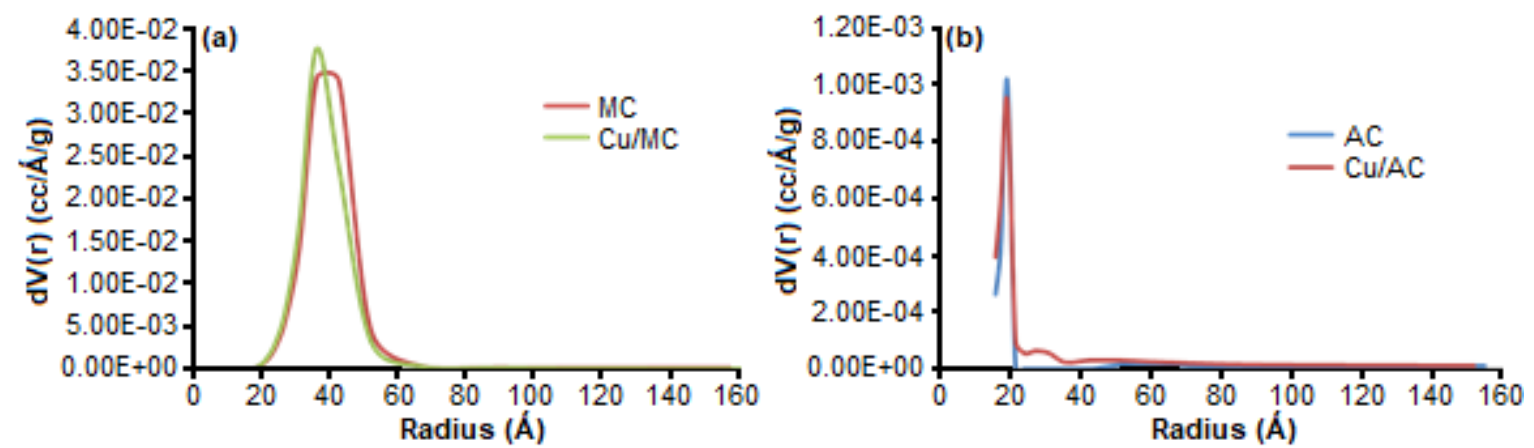

Fig 5. The pore size distribution of (a) $\mathrm{MC}$ and $\mathrm{Cu} / \mathrm{MC}$ and (b) $\mathrm{AC}$ and $\mathrm{Cu} / \mathrm{AC}$ calculated by BJH Desorption Method 
Table 1. Textural properties of $\mathrm{MC}, \mathrm{Cu} / \mathrm{MC}, \mathrm{AC}$, and $\mathrm{Cu} / \mathrm{AC}$

\begin{tabular}{lccccccc}
\hline Sample & $\begin{array}{c}\mathrm{S}_{\text {BET }}{ }^{\mathrm{a}} \\
\left(\mathrm{m}^{2} / \mathrm{g}\right)\end{array}$ & $\begin{array}{c}\mathrm{S}_{\text {ext }} \mathrm{b}^{\mathrm{b}} \\
\left(\mathrm{m}^{2} / \mathrm{g}\right)\end{array}$ & $\begin{array}{c}\mathrm{S}_{\text {micro }}{ }^{\mathrm{b}} \\
\left(\mathrm{m}^{2} / \mathrm{g}\right)\end{array}$ & $\begin{array}{c}\mathrm{V}_{\text {tot }}{ }^{\mathrm{c}} \\
(\mathrm{cc} / \mathrm{g})\end{array}$ & $\begin{array}{c}\mathrm{V}_{\text {meso }}{ }^{\mathrm{d}} \\
(\mathrm{cc} / \mathrm{g})\end{array}$ & $\begin{array}{c}\mathrm{V}_{\text {micro }}{ }^{\mathrm{d}} \\
(\mathrm{cc} / \mathrm{g})\end{array}$ & $\begin{array}{c}\text { Pore } \\
\text { Diameter }^{\mathrm{c}}(\AA)\end{array}$ \\
\hline $\mathrm{MC}$ & 405.78 & 287.44 & 118.34 & 0.67 & 0.60 & 0.06 & 72.32 \\
$\mathrm{Cu} / \mathrm{MC}$ & 388.68 & 262.23 & 126.44 & 0.64 & 0.58 & 0.06 & 66.24 \\
$\mathrm{AC}$ & 242.77 & 20.38 & 222.38 & 0.13 & 0.02 & 0.11 & 19.35 \\
$\mathrm{Cu} / \mathrm{AC}$ & 307.06 & 71.11 & 235.95 & 0.17 & 0.05 & 0.12 & 19.53 \\
\hline
\end{tabular}

Note: ${ }^{a}$ is determined by the BET method; ${ }^{b}$ is determined by the t-plot method; ${ }^{c}$ is determined by the highest point of $\mathrm{P}-\mathrm{P}_{0}$ (adsorption-desorption); ${ }^{\mathrm{d}}$ is determined by means of $\mathrm{V}_{\text {meso }}=\mathrm{V}_{\text {tot }}-\mathrm{V}_{\text {micro }}$

\section{Application of $\mathrm{Cu} / \mathrm{MC}$ as Catalyst for Carboxylation Reaction with $\mathrm{CO}_{2}$}

The phenylacetylene carboxylation reaction with $\mathrm{CO}_{2}$ was performed in the presence of $\mathrm{Cu} / \mathrm{MC}$ catalyst by varying reaction temperature $\left(25,50\right.$, and $\left.75{ }^{\circ} \mathrm{C}\right)$, the amount of catalysts $(28.6,57.2$, and $85.8 \mathrm{mg}$ ), the types of bases $\left(\mathrm{Cs}_{2} \mathrm{CO}_{3}, \mathrm{~K}_{2} \mathrm{CO}_{3}\right.$, and $\left.\mathrm{Na}_{2} \mathrm{CO}_{3}\right)$, and the types of support (mesoporous carbon and activated carbon), in $\mathrm{DMF}$ as solvent under $\mathrm{CO}_{2}$ pressure of $1 \mathrm{~atm}$ for $4 \mathrm{~h}$. The reaction is provided in Scheme 1, which shows that it could give two products: 3-phenylpropiolic acid as the main product and cinnamic acid as the side product [13]. The typical HPLC chromatogram of the reaction mixture is shown in Fig. 6. Three peaks appear in the chromatogram, which belongs to the unreacted phenylacetylene (retention time of $11 \mathrm{~min}$ ), cinnamic acid as the minor product (retention time of $6 \mathrm{~min}$ ), and phenylpropiolic acid as the main-product (retention time of $4 \mathrm{~min}$ ).

The carboxylation results are summarized in Fig. 7, in terms of percentage (\%) of phenylacetylene conversion. As shown in the graph, reaction temperature plays a significant role in the reaction. When the temperature is increased, the rate of phenylacetylene conversion also increases, with the highest conversion percentage obtained at $75^{\circ} \mathrm{C}(41 \%)$.

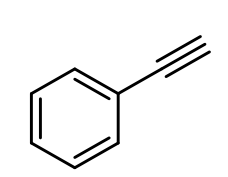

phenylacetylene

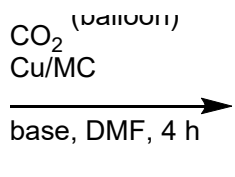

Schem<smiles>O=C(O)C#Cc1ccccc1</smiles>

phenylpropiolic acid<smiles>O=C(O)/C=C/c1ccccc1</smiles>

cinnamic acid

1. Carboxylation reaction of phenylacetylene with $\mathrm{CO}_{2}$

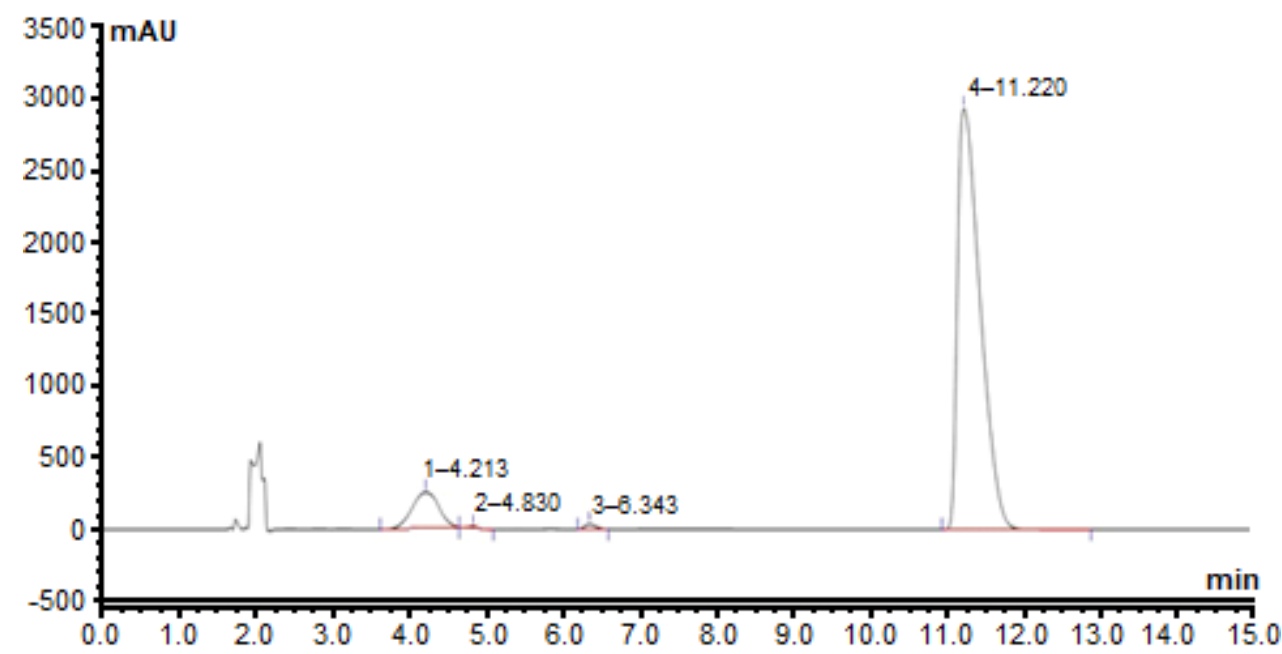

Fig 6. The typical HPLC chromatogram of the reaction mixture (reaction conditions: $\mathrm{Cs}_{2} \mathrm{CO}_{3}$ as the base at $75^{\circ} \mathrm{C}$ ) 


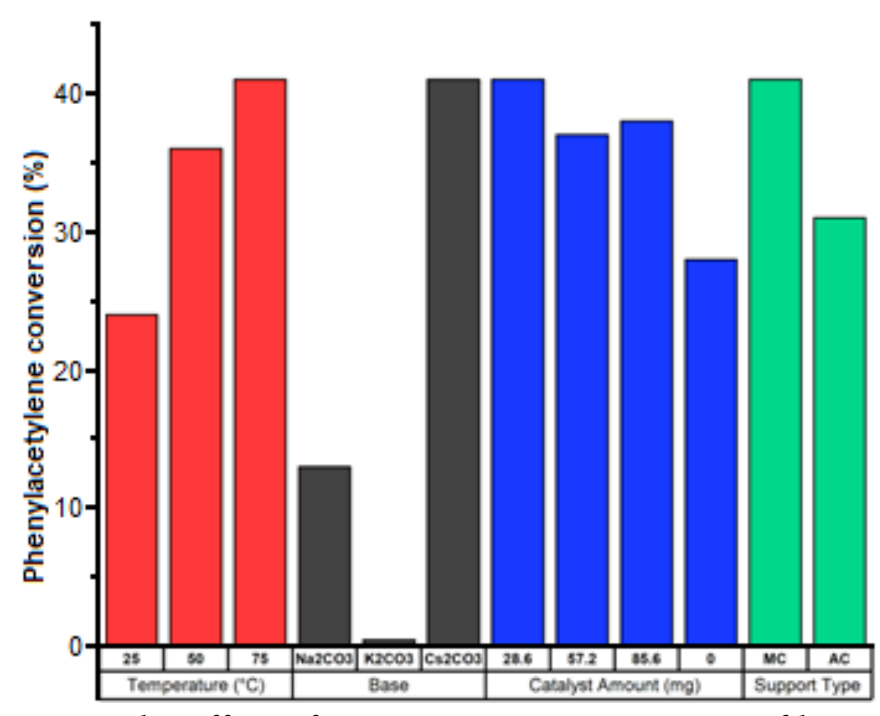

Fig 7. The effect of reaction temperature, type of bases, catalyst amount, and support type to phenylacetylene conversion in carboxylation reaction with $\mathrm{CO}_{2}$

This result indicates that phenylacetylene conversion is a thermal-dependent reaction. Compared to the Ag catalyst for the same reaction, copper exhibits similar catalytic activity. However, since the reaction time used in this study was quite short $(4 \mathrm{~h})$, the amount of phenylacetylene converted is lower than that of $\mathrm{Ag}$ catalyst for the reaction time of $16-36 \mathrm{~h}[1,10,15]$.

The type of base also influences the reaction, in which cesium carbonate provides superior results compared to the other two bases used $\left(\mathrm{Na}_{2} \mathrm{CO}_{3}\right.$ and $\mathrm{K}_{2} \mathrm{CO}_{3}$ ). This occurred because cesium carbonate is a stronger base than $\mathrm{Na}_{2} \mathrm{CO}_{3}$ and $\mathrm{K}_{2} \mathrm{CO}_{3}$; therefore, it is stronger in abstracting a proton from the terminal alkyne group in phenylacetylene, thus more feasible in facilitating the reaction. In addition to that, $\mathrm{Cs}_{2} \mathrm{CO}_{3}$ also has the highest solubility in DMF among the carbonate salts used [32]. Surprisingly, increasing the amount of the catalyst up to three times the original $(85.6 \mathrm{mg})$ did not increase the amount of phenylacetylene converted. However, in the absence of catalysts, the amount of phenylacetylene turned decreased to $28 \%$, indicating the catalyst's importance in the reaction.

We also compared mesoporous carbon to activated carbon as catalyst support. Activated carbon used is a commercial activated carbon that was modified using acid. The purpose of an acid modification is to add some oxygen groups, which are expected to increase adsorption ability [29]. As predicted, the reaction catalyzed by $\mathrm{Cu} / \mathrm{MC}$ has higher phenylacetylene conversion than that catalyzed by $\mathrm{Cu} / \mathrm{AC}$. The result is in line with the textural properties of the two materials. $\mathrm{Cu} / \mathrm{MC}$ poses a higher surface area, larger mesopore volume, and wider pore diameter that provides better reactant transport and facilitates the reaction better.

We also analyzed the reaction conditions on the formation of the products, and the results are presented in Fig. 8. Similar results were obtained for the effect of temperature, especially in the formation of the major products. When the reaction is carried out at a higher temperature, the major product (retention time of 4 min) increases significantly. However, unlike phenylacetylene conversion, base type did not give any different results on the products' formation. In the absence of any base, the products are hardly observed. Meanwhile, the amount of catalyst also did not have a different effect on the formation of major and minor products.

Interestingly, even without the presence of $\mathrm{Cu} / \mathrm{MC}$ catalyst (but in the presence of $\mathrm{Cs}_{2} \mathrm{CO}_{3}$ base), the product was still formed, though with a smaller percentage of converted reactants. A previous study by Dingyi and Yugen [33] reported using a stoichiometric amount of $\mathrm{Cs}_{2} \mathrm{CO}_{3}$ in direct carboxylation of terminal alkynes in the absence of a metal catalyst. Although the reaction proceeded well, it requires harsh reaction conditions such as high reaction temperature $\left(120^{\circ} \mathrm{C}\right)$ and higher $\mathrm{CO}_{2}$ pressure. This indicates that the catalyst plays a role in the adsorption and activation of the reactants, while the base plays a role in the further reaction process (related to hydrogen abstraction). Thus, the $\mathrm{Cu} / \mathrm{MC}$ catalyst plays a role in facilitating the reaction to take place under milder conditions. However, further studies regarding the reaction mechanism and each component's role need to be studied further. Finally, as in the case of phenylacetylene conversion, the type of support determines the amount of the products as well as its selectivity. In this case, $\mathrm{Cu} / \mathrm{MC}$ provides a higher amount of the products with selectivity leading to the formation of the major product. 

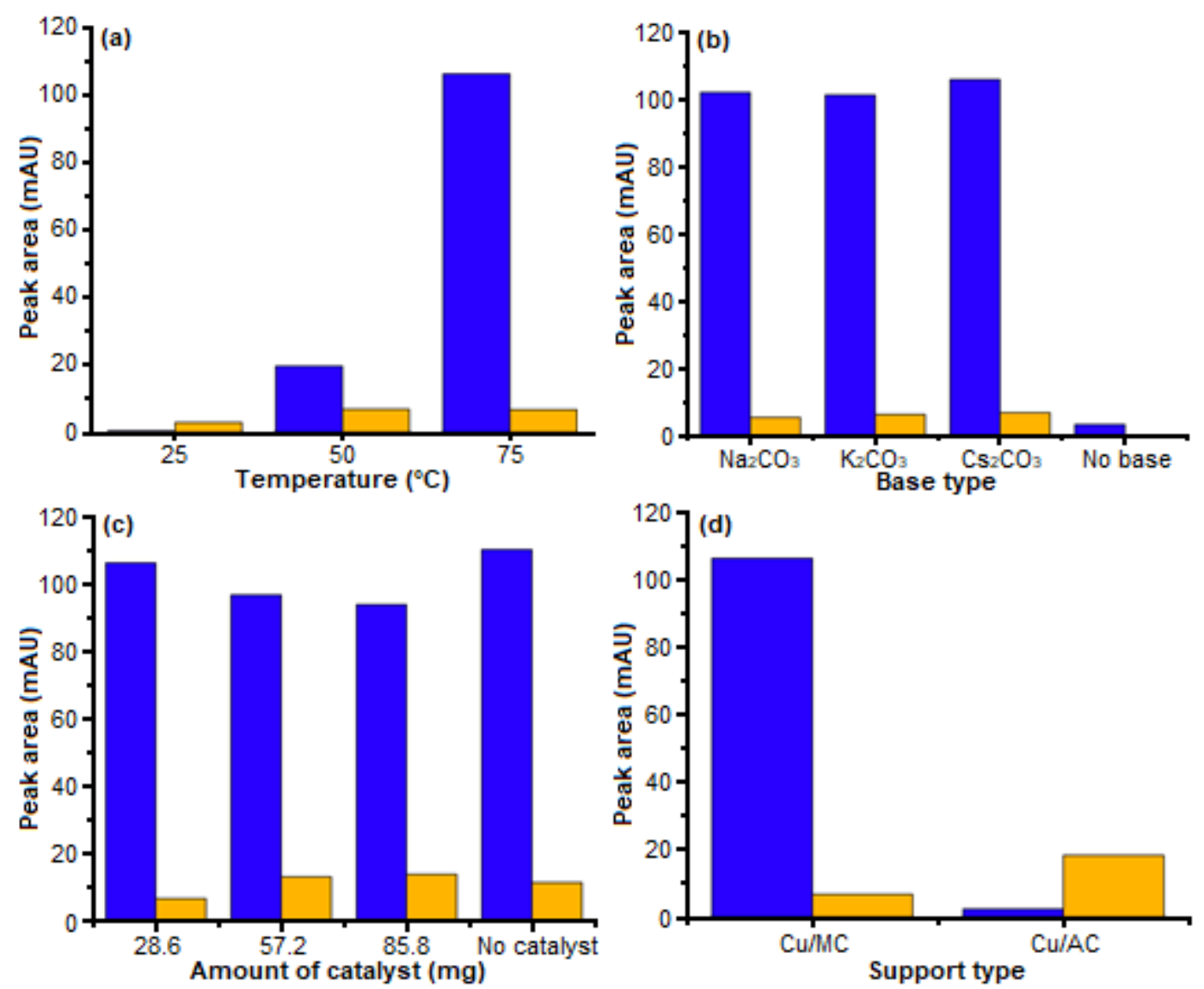

Fig 8. The effect of (a) reaction temperature, (b) the type of bases, (c) the amount of catalyst, and (d) the type of support to the peak area of the major product (blue chart) and minor product (yellow chart) in HPLC chromatography. $\mathrm{R}_{\mathrm{t}}$ of major product $=4 \mathrm{~min}, \mathrm{R}_{\mathrm{t}}$ of minor product $=6 \mathrm{~min}$

Fig. 9 shows the FTIR spectra of the product obtained at various reaction conditions. Based on this figure, it is known that there are peaks at $3200-3400 \mathrm{~cm}^{-1}$ derived from $\mathrm{O}-\mathrm{H}$ stretching, at $1720-1750 \mathrm{~cm}^{-1}$ from $\mathrm{C}=\mathrm{O}$ stretching of a carboxylic group, and at 1450 $1620 \mathrm{~cm}^{-1}$ that possibly comes from the $\mathrm{C}=\mathrm{C}$ stretching. The presence of peak $\mathrm{C}=\mathrm{O}$ stretching of a carboxylic group indicates that the phenylacetylene carboxylation reaction with $\mathrm{CO}_{2}$ has taken place.

In this work, we also conducted the study of phenylacetylene adsorption on $\mathrm{Cu} / \mathrm{MC}$ catalysts in $\mathrm{DMF}$ solvent to get some additional information on how the reactant interacts with the surface of the catalyst. The adsorption data were plotted using Langmuir, Freundlich, and Temkin Adsorption Isotherm Models. The Temkin Isotherm Models gave the most suitable result to describe the adsorption process with an $\mathrm{R}^{2}$ of 0.993 . Calculations

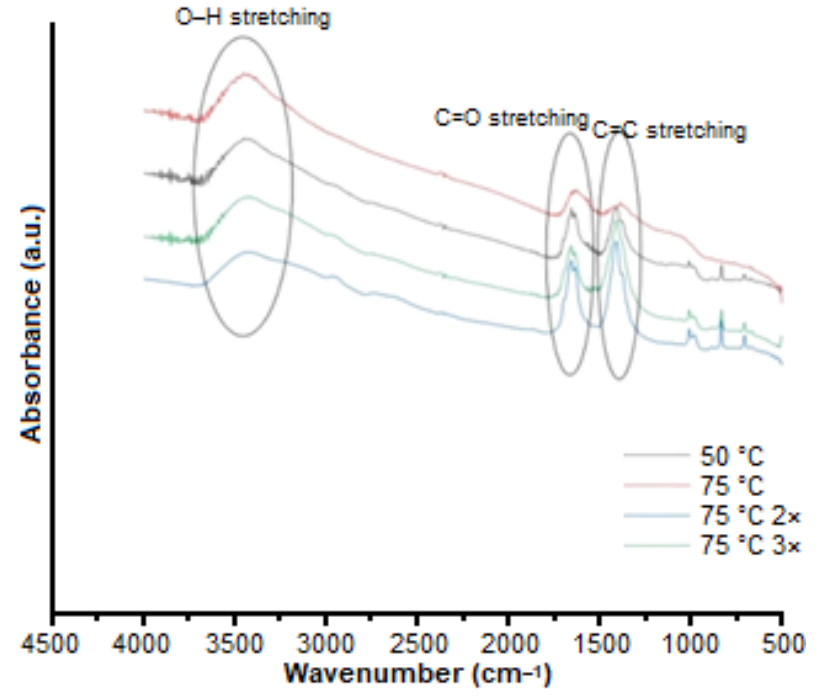

Fig 9. FTIR spectra of phenylacetylene carboxylation product obtained at various reaction conditions (at 50 , $75{ }^{\circ} \mathrm{C}$, and in the presence of the double and triple amount of the catalyst) 


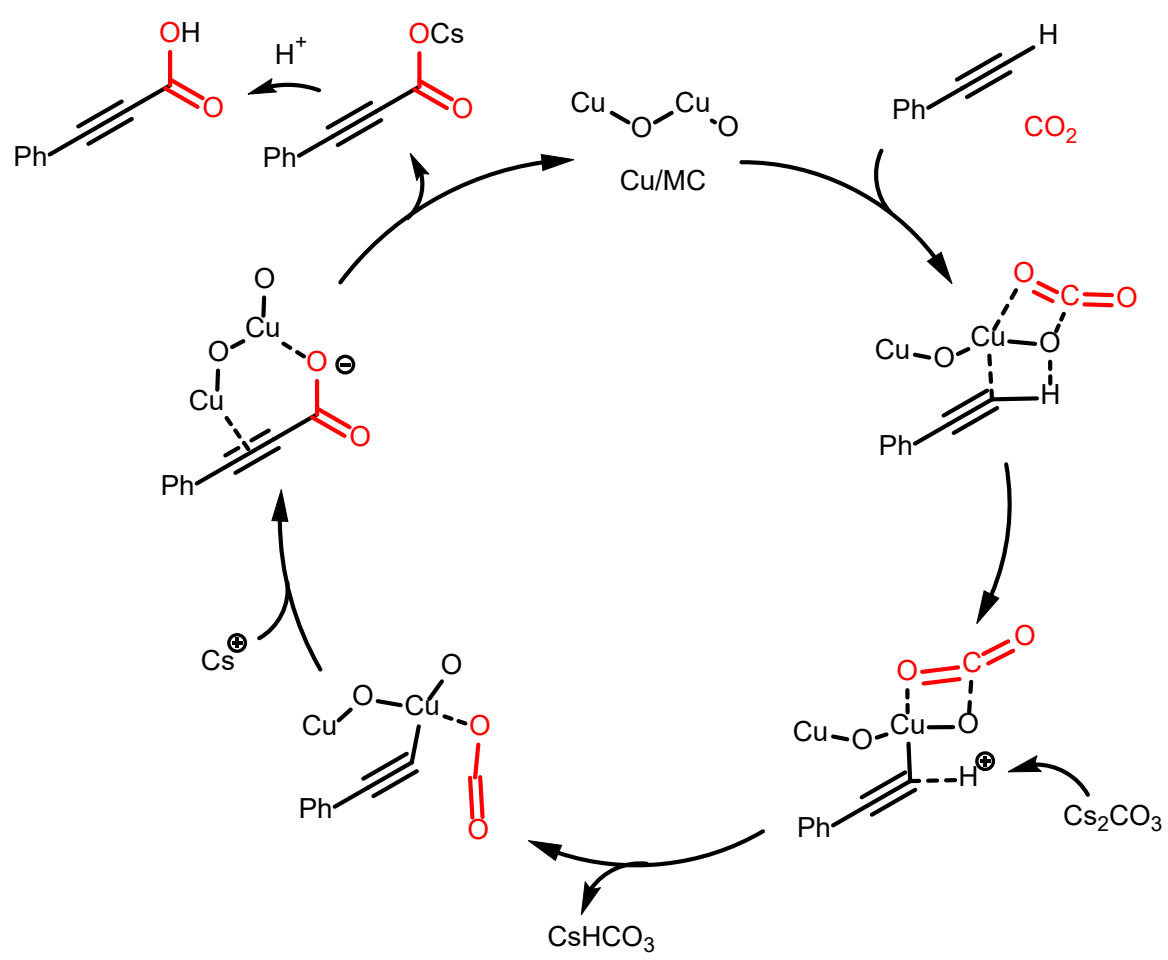

Fig 10. The proposed mechanism for phenylacetylene carboxylation on the surface of copper covered by copper oxides rewrites from Bondarenko et al. with some modifications [13]

from the linear regression equation provides the values of binding constant $\left(\mathrm{K}_{\mathrm{T}}\right)$ and adsorption energy $\left(\mathrm{b}_{\mathrm{T}}\right)$ at $298 \mathrm{~K}$ of $448 \mathrm{~L} / \mathrm{g}$ and $-2.696 \times 10^{7} \mathrm{~J} \mathrm{~g} \mathrm{~mol}^{-2}$, respectively. As Temkin Models fit best the data, the result indicates that the catalyst surface has a uniform distribution of binding energies, and the heat of adsorption of adsorbates decreases linearly with the increase of surface coverage [34-35].

Based on the results of the carboxylation reactions, the adsorption study, and the literature study, herein we proposed a mechanism for the catalytic carboxylation on the surface of copper covered by copper oxides. As shown in Fig. 10, the reaction starts with interactions between phenylacetylene, $\mathrm{CO}_{2}$, and $\mathrm{Cu} / \mathrm{MC}$ catalyst through weak hydrogen bonding and some dipole-dipole interactions. The presence of base is important for abstracting protons in the terminal alkyne of phenylacetylene, facilitating the insertion of $\mathrm{CO}_{2}$ to the alkyne part $[13,36]$. Another cesium cation would take part in a transmetallation reaction to produce cesium salt of the product as well as regenerate the catalyst. Finally, acidification of the salt would produce phenylpropiolic acid as the desired product.

\section{- CONCLUSION}

Copper impregnated on mesoporous carbon was successfully prepared and further tested as a catalyst for the carboxylation reaction of phenylacetylene with $\mathrm{CO}_{2}$ in the presence of a base. The impregnation changes the structure of mesoporous carbon, which including the surface area, pore-volume, and average pore size, which are found to be reduced. The carboxylation reaction of phenylacetylene took place at an optimum temperature of $75{ }^{\circ} \mathrm{C}$ and using $\mathrm{Cs}_{2} \mathrm{CO}_{3}$ as a base to produce 3phenylpropiolic acid as a major product and cinnamic acid as a minor product.

\section{- ACKNOWLEDGMENTS}

The authors gratefully acknowledge Universitas Indonesia for funding this research through the PITTA $B$ research grant with contract number NKB0635/UN2.R3.1/HKP.05.00/2019. 


\section{- REFERENCES}

[1] Wu, Z., Sun, L., Liu, Q., Yang, X., Ye, X., Hu, Y., and Huang, Y., 2017, A Schiff base-modified silver catalyst for efficient fixation of $\mathrm{CO}_{2}$ as carboxylic acid at ambient pressure, Green Chem., 19 (17), 20802085.

[2] Yu, B., Xie, J.N., Zhong, C.L., Li, W., and He, L.N., 2015, Copper(I)@carbon-catalyzed carboxylation of terminal alkynes with $\mathrm{CO}_{2}$ at atmospheric pressure, ACS Catal., 5 (7), 3940-3944.

[3] Wang, X., Nakajima, M., and Martin, R., 2015, Nicatalyzed regioselective hydrocarboxylation of alkynes with $\mathrm{CO}_{2}$ by using simple alcohols as proton sources, J. Am. Chem. Soc., 137 (28), 8924-8927.

[4] Doi, R., Abdullah, I., Taniguchi, T., Saito, N., and Sato, Y., 2017, Nickel-catalyzed hydrocarboxylation of ynamides with $\mathrm{CO}_{2}$ and $\mathrm{H}_{2} \mathrm{O}$ : Observation of unexpected regioselectivity, Chem. Commun., 53 (55), 7720-7723.

[5] Doi, R., Okano, T., Abdullah, I., and Sato, Y., 2019, Nickel-catalyzed $\beta$-carboxylation of ynamides with carbon dioxide, Synlett, 30 (9), 1048-1052.

[6] Williams, C.M., Johnson, J.B., and Rovis, T., 2008, Nickel-catalyzed reductive carboxylation of styrenes using $\mathrm{CO}_{2}$, J. Am. Chem. Soc., 130 (45), 14936-14937.

[7] Börjesson, M., Moragas, T., and Martin, R., 2016, Nicatalyzed carboxylation of unactivated alkyl chlorides with $\mathrm{CO}_{2}$, J. Am. Chem. Soc., 138 (24), 7504-7507.

[8] Boogaerts, I.I.F., Nolan, S.P., 2010, Carboxylation of $\mathrm{C}-\mathrm{H}$ bonds using $\mathrm{N}$-heterocyclic carbene gold(I) complexes, J. Am. Chem. Soc., 132 (26), 8858-8859.

[9] Steinmann, S.N., Michel, C., Schwiedernoch, R., Wu, M., and Sautet, P., 2016, Electro-carboxylation of butadiene and ethene over Pt and Ni catalysts, $J$. Catal., 343, 240-247.

[10] Shah, D.J., Sharma, A.S., Shah, A.P., Sharma, V.S., Athar, M., and Soni, J.Y., 2019, Fixation of $\mathrm{CO}_{2}$ as a carboxylic acid precursor by microcrystalline cellulose (MCC) supported AgNPs: A more efficient, sustainable, biodegradable and eco-friendly catalyst, New J. Chem., 43 (22), 8669-8676.
[11] Song, J., Liu, Q., Liu, H., and Jiang, X., 2018, Recent Advances in palladium-catalyzed carboxylation with $\mathrm{CO}_{2}$, Eur. J. Org. Chem., 2018 (6), 696-713.

[12] Whang, H.S., Lim, J., Choi, M.S., Lee, J., and Lee, H., 2019, Heterogeneous catalysts for catalytic $\mathrm{CO}_{2}$ conversion into value-added chemicals, $B M C$ Chem. Eng., 1 (1), 9.

[13] Bondarenko, G.N., Dvurechenskaya, E.G., Magommedov, E.S., and Beletskaya, I.P., 2017, Copper(0) nanoparticles supported on $\mathrm{Al}_{2} \mathrm{O}_{3}$ as catalyst for carboxylation of terminal alkynes, Catal. Lett., 147 (10), 2570-2580.

[14] Zhang, X., Zhang, W.Z., Ren, X., Zhang, L.L., and $\mathrm{Lu}, \quad$ X.B., 2011, Ligand-free $\mathrm{Ag}(\mathrm{I})$-catalyzed carboxylation of terminal alkynes with $\mathrm{CO}_{2}$, Org. Lett., 13 (9), 2402-2405.

[15] Yu, D., Tan, M.X., and Zhang, Y., 2012, Carboxylation of terminal alkynes with carbon dioxide catalyzed by poly(N-heterocyclic carbene)supported silver nanoparticles, Adv. Synth. Catal., 354 (6), 969-974.

[16] Wang, W.H., Jia, L., Feng, X., Fang, D., Guo, H., and Bao, M., 2019, Efficient carboxylation of terminal alkynes with carbon dioxide catalyzed by ligandfree copper catalyst under ambient conditions, Asian J. Org. Chem., 8 (8), 1501-1505.

[17] Liang, C., and Dai, S., 2006, Synthesis of mesoporous carbon materials via enhanced hydrogen-bonding interaction, J. Am. Chem. Soc., 128 (16), 5316-5317.

[18] Wang, X., Liang, C., and Dai, S., 2008, Facile synthesis of ordered mesoporous carbons with high thermal stability by self assembly of resorcinolformaldehyde and block copolymers under highly acidic conditions, Langmuir, 24 (14), 7500-7505.

[19] Cao, J.M., Cao, Y.L., Chang, X., Zheng, M.B., Liu, J.S., and Ji, H.M., 2005, Synthesis of silver nanoparticles within ordered CMK-3 mesoporous carbon, Stud. Surf. Sci. Catal., 156, 423-426.

[20] Li, J.G., Tsai, C.Y., and Kuo, S.W., 2014, Fabrication and characterization of inorganic silver and palladium nanostructures within hexagonal 
cylindrical channels of mesoporous carbon, Polymers, 6 (6), 1794-1809.

[21] Prasiwi, A.D., Trisunaryanti, W., Triyono, Falah, I.I., Santi, D., and Marsuki, M.F., 2019, Synthesis of mesoporous carbon from Merbau wood (Intsia spp.) by microwave method as Ni catalyst support for $\alpha$ cellulose hydrocracking, Indones. J. Chem., 19 (3), 575-582.

[22] Pamungkas, A.Z., Abdullah, I., and Krisnandi, Y.K., 2019, Synthesis and characterization of $\mathrm{Ni}$ nanoparticles supported on nitrogen-doped mesoporous carbon, IOP Conf. Ser.: Mater. Sci. Eng., 496, 012003.

[23] Liu, J., Wang, Z., Yan, X., and Jian, P., 2017, Metallic cobalt nanoparticles imbedded into ordered mesoporous carbon: A non-precious metal catalyst with excellent hydrogenation performance, J. Colloid Interface Sci., 505, 789-795.

[24] Liu, X., Lan, G., Su, P., Qian, L., Reina, T.R., Wang, L., Li, Y., and Liu, J., 2020, Highly stable Ru nanoparticles incorporated in mesoporous carbon catalysts for production of $\gamma$-valerolactone, Catal. Today, 351, 75-82.

[25] Şahin, N.E., Comminges, C., Valant, A.L., Kiener, J., Parmentier, J., Napporn, T.W., Melinte, G., Ersen, O., and Kokoh, K.B., 2018, One-pot soft-template synthesis of nanostructured copper-supported mesoporous carbon FDU-15 electrocatalysts for efficient $\mathrm{CO}_{2}$ reduction, ChemPhysChem, 19 (11), 1371-1381.

[26] Liu, L., Zhang, H., Wang, G., Du, J., Zhang, Y., Fu, X., and Chen, A., 2017, Synthesis of mesoporous carbon nanospheres via "pyrolysis-deposition"strategy for $\mathrm{CO}_{2}$ capture, J. Mater. Sci., 52 (16), 9640-9647.

[27] Ardhyarini, N., and Krisnandi, Y.K., 2017, Carbon dioxide capture by activated methyl diethanol amine impregnated mesoporous carbon, AIP Conf. Proc., 1862 (1), 030090.

[28] Pal, N., and Bhaumik, A., 2013, Soft templating strategies for the synthesis of mesoporous materials: Inorganic, organic-inorganic hybrid and purely organic solids, Adv. Colloid Interface Sci., 189-190, 21-41.

[29] Hosseini, S., Bayesti, I., Marahel, E., Babadi, F.E., Abdullah, L.C., and Choong, T.S.Y., 2015, Adsorption of carbon dioxide using activated carbon impregnated with $\mathrm{Cu}$ promoted by zinc, $J$. Taiwan Inst. Chem. Eng., 52, 109-117.

[30] Kooti, M., and Matouri, L., 2010, Fabrication of nanosized cuprous oxide using Fehling's solution, Sci. Iran., Trans. F, 17 (1), 73-78.

[31] Górka, J., Zawislak, A., Choma, J., and Jaroniec, M., 2008, KOH activation of mesoporous carbons obtained by soft-templating, Carbon, 46 (8), 11591161.

[32] Yuan, Z., 2014, Applications of bases in transition metal catalyzed reactions, Postdoc J., 2 (3), 17-28.

[33] Dingyi, Y., and Yugen, Z., 2011, The direct carboxylation of terminal alkynes with carbon dioxide, Green Chem., 13 (5), 1275-1279.

[34] Piccin, J.S., Dotto, G.L., and Pinto, L.A.A., 2011, Adsorption isotherms and thermochemical data of FD\&C Red $\mathrm{n}^{\circ} 40$ binding by chitosan, Braz. J. Chem. Eng., 28 (2), 295-304.

[35] Ayawei, N., Ebelegi, A.N., and Wankasi, D., 2017, Modelling and interpretation of adsorption isotherms, J. Chem., 2017, 3039817.

[36] Wu, Z., Liu, Q., Yang, X., Ye, X., Duan, H., Zhang, J., Zhao, B., and Huang, Y., 2017, Knitting aryl network polymers-incorporated Ag nanoparticles: A mild and efficient catalyst for the fixation of $\mathrm{CO}_{2}$ as carboxylic acid, ACS Sustainable Chem. Eng., 5 (11), 9634-9639. 